\title{
Effect of feeding a palmitic acid-enriched supplement on production responses and nitrogen metabolism of mid-lactating Holstein and Jersey cows
}

\author{
Austin Sears, ${ }^{1}$ Osvaldo Gonzalez, ${ }^{1}$ Anthony Alberto, ${ }^{1}$ Allen Young, ${ }^{1}$ Jonas de Souza, ${ }^{2} \odot$ Alejandro Relling, ${ }^{3} \odot$ \\ and Fernanda Batistel ${ }^{1 *}$ (c) \\ ${ }^{1}$ Animal, Dairy and Veterinary Sciences Department, Utah State University, Logan 84322 \\ ${ }^{2}$ Perdue Agribusiness, Salisbury, MD 21804 \\ ${ }^{3}$ Department of Animal Sciences, The Ohio State University, Wooster 44691
}

\begin{abstract}
This study evaluated the effect of feeding a palmitic acid-enriched supplement on production responses and nitrogen metabolism of mid-lactating Holstein and Jersey cows. Eighty mid-lactating dairy cows, 40 Holstein and 40 Jersey, were used in a randomized complete block design with a split-plot arrangement; the main plot was breed and the subplot was fatty acid treatment. Cows within each breed were assigned to 1 of 2 treatments: (1) control diet with no fat supplement or (2) control diet plus a palmitic acid-enriched supplement dosed at $1.5 \%$ of diet dry matter (PA treatment). The treatment period was $6 \mathrm{wk}$ with the final $3 \mathrm{wk}$ used for data and sample collection. There were no treatment $\times$ breed interactions for the variables analyzed. Compared with control, PA treatment increased milk fat yield (1.36 vs. $1.26 \mathrm{~kg} / \mathrm{d}$ ) and tended to increase $3.5 \%$ fat-corrected milk (35.6 vs. $34.0 \mathrm{~kg} / \mathrm{d})$ and energy-corrected milk $(35.7$ vs. $34.1 \mathrm{~kg} / \mathrm{d})$. There was no effect of PA treatment on dry matter intake, milk yield, milk protein yield, milk lactose yield, body condition score, body weight (BW) change, nitrogen intake, and variables related to nitrogen metabolism and excretion. Compared with Holstein cows, Jersey cows had greater dry matter intake as a percent of BW (4.90 vs. $3.37 \%$ of BW) and lower milk production (29.6 vs. $32.7 \mathrm{~kg} / \mathrm{d})$ and milk lactose yield (1.58 vs. $1.42 \mathrm{~kg} / \mathrm{d}$ ), but tended to have greater milk fat yield (1.36 vs. $1.26 \mathrm{~kg} / \mathrm{d})$. There was a breed effect on BW change; Holstein cows gained 0.385 $\mathrm{kg} / \mathrm{d}$ during the experiment, and Jersey cows gained $0.145 \mathrm{~kg} / \mathrm{d}$. Jersey cows had lower nitrogen intake $(636$ vs. $694 \mathrm{~g} / \mathrm{d}$ ), blood urea nitrogen (12.6 vs. $13.8 \mathrm{mg} /$ $\mathrm{dL}$ ), urine total nitrogen (125 vs. $145 \mathrm{~g} / \mathrm{d}$ ), and urine total nitrogen as a percent of nitrogen intake (19.5 vs.
\end{abstract}

Received January 20, 2020.

Accepted May 11, 2020

*Corresponding author: fernanda.batistel@usu.edu
21.1\%). Overall, feeding a palmitic acid-enriched supplement increased milk fat yield as well as dry matter and fiber digestibility in both Holstein and Jersey cows. The PA treatment did not have any major effects on nitrogen metabolism in both Holstein and Jersey cows. In addition, our results indicated that Jersey cows had lower urinary nitrogen excretion $(\mathrm{g} / \mathrm{d})$ than Holstein cows.

Key words: fatty acids, milk fat, milk protein, nitrogen excretion

\section{INTRODUCTION}

Fat supplements are commonly fed to dairy cow diets as a strategy to increase dietary energy density, increase yields of milk and milk fat, and improve energy balance (Rabiee et al., 2012). Recent research indicates that the fatty acid profile of supplemental fat is a major factor affecting dairy cow performance (de Souza et al., 2018). Palmitic acid supplementation has shown to consistently increase the concentration and yield of milk fat (Lock et al., 2013; Mathews et al., 2016), DM digestibility, and feed efficiency (Rico et al., 2017; de Souza et al., 2018) compared with diets without supplemental fat. From an economic standpoint (the component pricing system most commonly used for milk sales), milk fat increases can result in greater monetary return for the producer. However, to our knowledge, the effects of dietary palmitic acid supplementation have been evaluated only with Holstein cows, and it is well established that milk composition is largely affected by breed. Therefore, determining whether the effects of palmitic acid supplementation are consistent across different dairy cow breeds is of particular importance.

Jersey cows have a greater milk fat content and a greater proportion of short- and medium-chain milk fatty acids than Holstein cows (Beaulieu and Palmquist, 1995; Palladino et al., 2010). Additionally, breed differences may affect the utilization and partitioning of 
supplemental fat as well as milk fat synthesis. Beaulieu and Palmquist (1995) observed that feeding incremental levels of Ca salts of palm fatty acid distillate increased the ratio of oleic:stearic acids in Holstein cows' milk, but no effects were observed in Jersey cows, suggesting a different mechanism of regulating milk fat synthesis. In most studies, feeding palmitic acid enhanced milk fat yield due to greater incorporation of 16-carbon fatty acids (Rico et al., 2014a; de Souza and Lock, 2018). However, changes in the yield of some short- and longchain fatty acids (e.g., butyric and oleic acids) have also been reported (Rico et al., 2014b; de Souza and Lock, 2019b). When compared with Holstein, Jersey cows contain a greater proportion of de novo fatty acids and palmitic acid in milk fat (Beaulieu and Palmquist, 1995). Breed differences may exist for fat utilization because feeding an exogenous source of fatty acids may affect de novo synthesis of milk fat, and its regulation may differ across breeds (Beaulieu and Palmquist, 1995; Palmquist, 2006). Overall, the regulation of milk fat synthesis appears to be different among breeds and because feeding palmitic acid can affect it, it is important to understand how palmitic acid supplementation affects milk fat yield and composition in Holstein and Jersey cows.

Nitrogen release into the environment from animal agriculture has become an increasing area of concern. Nitrogen escape from urine and feces of dairy cows can be reduced with better diet combinations and management practices (Powell et al., 2006). Much interest has been given to investigating specific ways to reduce nitrogen losses without affecting the production performance of cows. It is widely accepted that increasing the carbohydrate availability will decrease ammonia production by incorporating nitrogen into microbial protein (Russell et al., 1983). Palmitic acid could have an indirect effect on nitrogen metabolism in the rumen, as previous experiments have reported an increase in fiber and DM digestibility (Piantoni et al., 2013; de Souza and Lock, 2018), suggesting that dietary fatty acids can affect microbial population and energy utilization. Vargas-Bello-Pérez et al. (2016) reported that a diet supplemented with hydrogenated palm oil (2.7\% of diet DM; $47 \%$ palmitic acid, and $43 \%$ stearic acid) increased ruminal total bacteria compared with a nonfat control diet and soybean oil, indicating a potential role of the fatty acid profile on rumen microbial population. Therefore, if dietary saturated fatty acids can alter microbial population and favor microbial growth, a better utilization of nitrogen in the rumen could be expected.

The objective of this experiment was to determine the effects of feeding a palmitic acid-enriched supplement on milk yield and components, milk fatty acid composition, nutrient digestibility, and nitrogen metab- olism compared with feeding soyhulls on Holstein and Jersey cows. We hypothesized that Jersey cows would have a greater fat yield response to the palmitic acid supplement when compared with Holstein cows, and that both breeds would have lower nitrogen excretion with the addition of palmitic acid.

\section{MATERIALS AND METHODS}

\section{Animal Housing and Care}

The Institutional Animal Care and Use Committee at Utah State University (Logan, UT) approved all experimental procedures (protocol \#10145). All cows were housed in a freestall system with sand bedding and water available ad libitum. Two Lely Astronaut A4 automatic milking systems (Lely Industries N.V., Maassluis, the Netherlands) were used. Cows were milked by free choice and the average daily milking per cow during the experiment was 2.5. The cows had free access to the milking system for $22 \mathrm{~h} / \mathrm{d}$, with the remaining time dedicated to cleaning. To ensure a minimum twicedaily milking frequency, cows that had not voluntarily entered the automatic milking system in more than 10 $\mathrm{h}$ since the previous milking were fetched to be milked. Standard reproduction, health herd checks, and breeding practices were maintained during this study.

\section{Design and Treatment Diets}

Eighty multiparous mid-lactating cows (40 Holstein and 40 Jersey) from the Utah State University Caine Dairy Research Farm (Wellsville, UT) were used in a randomized complete block design with a split-plot arrangement, where the main plot was breed and subplot the fatty acid treatment. All animals received a common diet during the 14-d preliminary period to obtain baseline values. Experimental diets were fed for $6 \mathrm{wk}$, including $3 \mathrm{wk}$ for diet adaptation and $3 \mathrm{wk}$ for sample collection. Cows were blocked by milk production during the preliminary period, and the blocks were balanced by parity and DIM (Supplemental Table S1, https://doi.org/10.3168/jds.2020-18232). At the start of the experiment, the cows were at $145 \pm 31$ $\mathrm{DIM}$ (mean $\pm \mathrm{SD}$ ) and had $3.0 \pm 1.4$ parities. Cows within each breed were assigned to 1 of 2 treatments. Treatment diets were a control diet with no fat supplement or the control diet plus a palmitic acid-enriched supplement (PA; Spectrum Fusion, Purdue AgriBusiness LLC, Salisbury, MD), dosed at $1.5 \%$ of diet DM (supplement contained in $\mathrm{g} / 100 \mathrm{~g}$ of fatty acids 0.45 C14:0, 82.5 C16:0, 4.55 C18:0, and 9.85 cis-9 C18:1). Cows received the control or treatment diets as a concentrate mix fed individually in the automatic milking 
Table 1. Ingredient and nutrient composition $( \pm \mathrm{SD})$ of treatment diets fed to mid-lactation Jersey and Holstein cows

\begin{tabular}{lcc}
\hline & \multicolumn{2}{c}{ Treatment } \\
\cline { 2 - 3 } Item & Control & Palmitic acid \\
\hline Ingredient, \% of DM & \\
Corn silage & 21.5 & 21.5 \\
Alfalfa hay & 25.0 & 25.0 \\
Oat hay & 3.47 & 3.47 \\
Ground corn & 2.60 & 2.60 \\
Steam-flaked corn & 12.5 & 12.5 \\
Wheat middlings & 6.23 & 6.23 \\
Soybean meal & 3.12 & 3.12 \\
Canola meal & 5.21 & 5.21 \\
Amino acid supplement ${ }^{1}$ & 0.78 & 0.78 \\
Beat pulp & 6.98 & 6.98 \\
Soyhulls & 3.47 & 2.00 \\
Whole cottonseed & 5.13 & 5.13 \\
Molasses & 0.50 & 0.50 \\
Palmitic acid supplement ${ }^{2}$ & 0.00 & 1.48 \\
Mineral and vitamin mix & 3.47 & 3.47 \\
Nutrient composition, \% of DM & & \\
NE ${ }^{3}{ }^{3}$ Mcal/kg & $1.45 \pm 0.01$ & $1.54 \pm 0.01$ \\
NDF & $30.3 \pm 0.46$ & $29.8 \pm 0.44$ \\
Forage NDF & $21.3 \pm 0.22$ & $21.3 \pm 0.23$ \\
CP & $17.5 \pm 0.32$ & $17.5 \pm 0.31$ \\
Starch & $23.1 \pm 0.25$ & $23.1 \pm 0.27$ \\
Total fatty acids & $2.39 \pm 0.07$ & $3.84 \pm 0.06$ \\
\hline
\end{tabular}

${ }^{1}$ Spectrum AgriBlue amino acid supplement; Perdue AgriBusiness, Salisbury, MD

${ }^{2}$ Spectrum Fusion palmitic acid supplement; Perdue AgriBusiness.

${ }^{3}$ Net energy of lactation predicted based on NRC (2001).

system. The amount of concentrate mix offered daily was 3.60 and $4.0 \mathrm{~kg} / \mathrm{d}$ of DM for Jersey and Holstein cows, respectively. The concentrate mix amount was calculated assuming a predicted intake of 22.5 and 25.0 $\mathrm{kg} / \mathrm{d}$ for Jersey and Holstein cows, respectively, according to NRC (2001). All cows received the same partial mixed ration (PMR) that was mixed daily in a vertical mixer and delivered once per day $(0630 \mathrm{~h})$ at $\sim 120 \%$ of the expected intake. The concentrate mix and PMR represented 16 and $84 \%$ of predicted total DMI. The ingredient and nutrient composition of the diets fed are reported in Table 1. All rations were formulated to meet cow-predicted requirements according to NRC (2001).

\section{Data and Sample Collection and Analysis}

Weekly samples of feed ingredients, PMR, concentrate mix, and feed refusals were collected and dried at $65^{\circ} \mathrm{C}$ for $72 \mathrm{~h}$, ground through a 1-mm screen with a Wiley mill (Arthur H. Thomas, Philadelphia, PA), and analyzed for DM (AOAC International, 2000), NDF (Van Soest et al., 1991), CP (AOAC International, 2000), starch (Hall, 2009), and fatty acids (Sukhija and Palmquist, 1988) with modifications (Lock et al., 2013). Fatty acids were determined using a one-step transesterification method. Briefly, $1 \mathrm{mg}$ of cis-10 C17:1 diluted in acetone was used as an internal standard. Fatty acid methyl esters were then prepared by adding $5 \%$ methanolic sulfuric acid to the samples. Samples were incubated overnight $\left(50^{\circ} \mathrm{C}\right)$, allowed to cool down, and neutralized with a $5 \%$ sodium chloride solution. The solvent layer was washed with a $6 \%$ aqueous potassium bicarbonate solution and dried over anhydrous sodium sulfate. The FAME were filtered through silica gel and charcoal and the solvents were removed under nitrogen flux at $37^{\circ} \mathrm{C}$. The FAME were then weighed, and a $1 \%$ solution with n-hexane was prepared on a weight basis, which was used for GLC analysis. The FAME were determined by GLC equipped with a split injector (1:100 split ratio) using a CP8827 WCOT fused-silica column $(30 \mathrm{~m} \times$ $0.32 \mathrm{~mm}$ i.d. $\times 0.25 \mu \mathrm{m}$ film thickness; Varian Inc., Palo Alto, CA). Injector and detector temperature was kept at $270^{\circ} \mathrm{C}$. The oven program was as follows: initial temperature of $140^{\circ} \mathrm{C}$ and held for $1 \mathrm{~min}$, programmed at $5^{\circ} \mathrm{C} / \mathrm{min}$ to $225^{\circ} \mathrm{C}$, then programmed at $50^{\circ} \mathrm{C} / \mathrm{min}$ to $250^{\circ} \mathrm{C}$ held for $5.5 \mathrm{~min}$.

Milk production was recorded daily, and 2 consecutive milk samples per individual cow were collected once a week, composited based on milk yield, and stored with preservatives at $4^{\circ} \mathrm{C}$ before analysis of fat, protein, lactose, SNF, and MUN by mid-infrared procedures (Rocky Mountain DHIA Laboratory, Logan, UT). Based on milk analysis, the ECM and 3.5\% FCM were calculated as follows:

$$
\begin{gathered}
\mathrm{ECM}=[12.82 \times \text { fat yield }(\mathrm{kg})] \\
+[7.13 \times \text { protein yield }(\mathrm{kg})] \\
+[0.323 \times \text { milk yield }(\mathrm{kg})] ; \\
\mathrm{FCM}=(0.4324 \times \mathrm{kg} \text { of milk yield }) \\
+(16.216 \times \mathrm{kg} \text { of milk fat }) .
\end{gathered}
$$

Milk protein nitrogen $(\mathrm{g} / \mathrm{d})$ was calculated as $[(\mathrm{milk}$ protein yield $(\mathrm{kg}) \times 1,000) / 6.38]$ and milk nitrogen efficiency was obtained by dividing the amount of nitrogen in the milk by the daily nitrogen consumed.

Milk samples used for fatty acid composition were composited based on milk fat yield by individual cow and stored at $-20^{\circ} \mathrm{C}$ until milk lipids were extracted and fatty acid composition determined by gas chromatograph according to Hara and Radin (1978) with modifications (Lock et al., 2013). Briefly, composite samples $(\sim 50 \mathrm{~mL})$ were centrifuged (30 min, 17,800 $\times$ $g$ at $4^{\circ} \mathrm{C}$ ), and the fat cake was collected. Total lipids from the fat cake were extracted using n-hexane/ isopropanol $(3: 2, \mathrm{vol} / \mathrm{vol})$. Fatty acid methyl esters were prepared by shaking a mixture of $2.5 \mathrm{~mL}$ of $\mathrm{n}$ - 
hexane containing $25 \mathrm{mg}$ of lipids and $0.5 \mathrm{~mL}$ of 0.5 $M$ sodium methoxide solution in methanol for $5 \mathrm{~min}$. After centrifugation $\left(5 \mathrm{~min}, 6,000 \times g\right.$ at $\left.8^{\circ} \mathrm{C}\right)$, the supernatant containing the FAME was used for GLC analysis. Fatty acid composition was determined by GLC (Weiss et al., 2013) using a CP-SIL88 capillary column $(100 \mathrm{~m} \times 0.25 \mathrm{~mm} \times 0.2 \mu \mathrm{m}$ film thickness; Varian Inc.). Instrument conditions were as follows: an injector temperature of $250^{\circ} \mathrm{C}$, a flame-ionization detector temperature of $255^{\circ} \mathrm{C}$, hydrogen carrier gas at 0.8 $\mathrm{mL} / \mathrm{min}$, detector makeup gas $\left(\mathrm{N}_{2}\right)$ at $20 \mathrm{~mL} / \mathrm{min}$, and an injector split ratio of 75:1. The initial column temperature was $100^{\circ} \mathrm{C}$, programmed at $6^{\circ} \mathrm{C} / \mathrm{min}$ to $170^{\circ} \mathrm{C}$ for $50 \mathrm{~min}$, and then $8^{\circ} \mathrm{C} / \mathrm{min}$ to $220^{\circ} \mathrm{C}$ for $20 \mathrm{~min}$. The yield of individual fatty acids $(\mathrm{g} / \mathrm{d})$ in milk fat was calculated by correcting for glycerol content according to Schauff et al. (1992), and other milk lipid classes were calculated according to Glasser et al. (2007). The transfer efficiency was calculated according to de Souza and Lock (2019b), where FA is fatty acid:

\section{[(FA yield for treatment diet}

- FA yield for control diet)/(FA intake for treatment

$$
\text { diet }- \text { FA intake for control diet) }] \times 100 \text {. }
$$

Body weight was recorded daily by the automatic milking system, and BCS was recorded twice, at the first and last day of the experiment. Body weight change was calculated using a linear regression applied to BW measurements of individual cows, and the slope of the fitted line represented the cow's BW change (Hardie et al., 2015). Body condition score was scored by 2 trained investigators using a 5 -point scale where $1=$ thin and 5 = fat (Wildman et al., 1982). Rumination time and activity data were collected by electronic ruminationdetection loggers on the neck collar of each cow in 2-h intervals (Lely Qwes-HR collars, Lely Industries N.V.). The collection of rumination data using these collars has been validated by Schirmann et al. (2009).

To calculate total DMI (concentrate mix intake + PMR intake), concentrate mix intake was measured daily and PMR intake was estimated from total fecal excretion and feed digestibility using external and internal markers once at the end of the trial. To estimate total fecal excretion, capsules containing $10 \mathrm{~g}$ of titanium dioxide $\left(\mathrm{TiO}_{2}\right)$ were administered twice daily at 0600 and $1700 \mathrm{~h}$ with balling guns throughout the last $15 \mathrm{~d}$ of the experiment to estimate DMI as previously described by Batistel et al. (2017). Fecal grab samples were collected from each cow during the last $5 \mathrm{~d}$ of the experiment at 15 -h intervals and frozen at $-20^{\circ} \mathrm{C}$ until further analysis. Samples were thawed and composed by cow, weighed, dried in a $65^{\circ} \mathrm{C}$ forced-air oven for 48 to $72 \mathrm{~h}$ for DM determination, and ground through a 1-mm screen with a Wiley mill. Concentrations of $\mathrm{TiO}_{2}$ were used to estimate fecal output according to Myers et al. (2004). To estimate in vivo feed digestibility, indigestible NDF was used as a marker; fecal and feed samples were incubated in triplicate and indigestible NDF was estimated as NDF residue after 288-h in vivo fermentation (Bender et al., 2016). Total fecal excretion, fecal excretion coming from the concentrate mix (FEC), PMR intake, and total DMI intake were calculated as follows: (1) total fecal excretion $=$ amount of $\mathrm{TiO}_{2}$ dosed $(\mathrm{g} / \mathrm{d}) /$ concentration of $\mathrm{TiO}_{2}$ in feces $(\mathrm{g} / \mathrm{kg}),(2) \mathrm{FEC}=$ concentrate mix intake $(\mathrm{kg} / \mathrm{d}) \times$ concentrate mix indigestibility (\%), (3) PMR intake = total fecal excretion $(\mathrm{kg} / \mathrm{d})-\mathrm{FEC}(\mathrm{kg} / \mathrm{d}) / \mathrm{PMR}$ indigestibility, and (4) total DMI = concentrate mix intake $(\mathrm{kg} / \mathrm{d})+$ PMR intake $(\mathrm{kg} / \mathrm{d})$.

To estimate nutrient digestibility, indigestible NDF was used as an internal marker to estimate apparent total-tract digestibility of nutrients (Cochran et al., 1986). Fecal samples were analyzed for DM, NDF, and fatty acids. Neutral detergent fiber was determined with heat-stable $\alpha$-amylase and sodium sulfite method (Van Soest et al., 1991). Fatty acids from feces were extracted with a 2-step methylation procedure, as described by Jenkins (2010). An internal standard (cis-10 C17:1) was added to the oven-dried ground fecal samples as described above for feed ingredients and orts.

Blood was sampled from the coccygeal vein or artery at $0900 \mathrm{~h}$ once per week during the sampling period. Samples were collected into evacuated tubes (BD Vacutainer, BD and Co., Franklin Lakes, NJ) containing lithium heparin. After blood collection, samples were placed in ice until centrifugation $(\sim 40 \mathrm{~min})$. Plasma was obtained by centrifugation at $3,000 \times g$ for $15 \mathrm{~min}$ at $4^{\circ} \mathrm{C}$. Aliquots of plasma were frozen $\left(-40^{\circ} \mathrm{C}\right)$ until further analysis. Plasma urea nitrogen concentrations were measured using a colorimetric detection kit (cat. no. K024-H1, Arbor Assays, Ann Arbor, MI).

Spot urine samples were collected from each cow once a week during the sampling period. Samples were acidified with $\mathrm{H}_{2} \mathrm{SO}_{4}(\mathrm{pH}$ of urine $<5)$ and stored at $-20^{\circ} \mathrm{C}$ until further analysis. Creatinine was analyzed using a colorimetric detection kit (cat. no. K002-H1, Arbor Assays) and total nitrogen was analyzed using the Kjeldahl method (AOAC, 1990). Total urine production was calculated by creatinine content of each sample, assuming that excretion of creatinine was constant at $0.213 \mathrm{mmol} / \mathrm{kg}$ of BW (Chizzotti et al., 2008). Nitrogen intake was calculated from intakes of concentrate mix and PMR and their respective nitrogen contents. Apparent milk nitrogen efficiency (assuming no retention 
or mobilization of body nitrogen) was calculated for each cow by dividing mean milk nitrogen output (milk $\mathrm{CP} / 6.38$ ) by total nitrogen intake. Urinary nitrogen excretion was calculated from total urine production multiplied by its nitrogen content.

\section{Statistical Analysis}

Data were analyzed using the MIXED procedure of SAS v.9.4 (SAS Institute Inc. Cary, NC) according to the following model:

$$
\begin{aligned}
Y_{i j k l}= & \mu+b_{i}+B_{j}+T_{k}+P_{l}+B P_{j l} \\
& +T P_{k l}+B T P_{j k l}+e_{i j k l},
\end{aligned}
$$

where $Y_{i j k l}=$ variable of interest; $\mu=$ overall mean; $b_{i}$ $=$ random effect of block; $B_{j}=$ fixed effect of breed $(j$ $=$ Holstein or Jersey); $T_{k}=$ fixed effect of treatment $(k$ $=$ control or palmitic acid); $P_{l}=$ fixed effect of time; $B P_{j l}=$ interaction between breed and time; $T P_{k l}=$ interaction between treatment and time; $B T P_{j k l}=$ interaction between breed, treatment, and time; and $e_{i j k l}$ $=$ residual error. Preliminary, milk yield was used as a covariate and when not significant $(P>0.15)$ it was removed from the model. Total DMI and BW change generated a single estimate per cow, and thus a reduced model was used to remove the effect of time and interaction between breed, treatment, and time. We used first-order autoregression as the covariate structure for repeated measures analysis because it resulted in the lowest Bayesian information criterion for most of the variables measured. The normality of the residuals was checked with normal probability and box plots, and homogeneity of variances was checked with plots of residuals versus predicted values. Significance was determined at $P \leq 0.05$ and tendencies at $P \leq 0.10$.

\section{RESULTS}

\section{Animal Production}

There was no treatment $x$ breed interaction for any production response measured ( $P \geq 0.11$; Table 2). Compared with control, PA treatment increased milk fat yield (1.36 vs. $1.26 \mathrm{~kg} / \mathrm{d}, P=0.03)$, milk fat content ( $4.54 \%$ vs. $4.24 \%, P=0.01$ ), and milk protein content (3.61\% vs. $3.50 \%, P=0.03$ ), and tended to increase FCM $(35.6$ vs. $34.0 \mathrm{~kg} / \mathrm{d}, P=0.09)$ as well as ECM (35.7 vs $34.1 \mathrm{~kg} / \mathrm{d}, P=0.10$; Table 2$)$. Compared with control, there were no effects of PA treatment on DMI $(P=0.47), \mathrm{DMI}$ as a percent of $\mathrm{BW}(P=0.79)$, rumination time $(P=0.58)$, milk yield $(P=0.68)$, milk protein yield $(P=0.22)$, milk lactose yield $(P=0.74)$, BW change $(P=0.91)$, or BCS $(P=0.76)$.

Compared with Holsteins, Jerseys had lower DMI $(22.7$ vs. $25.0 \mathrm{~kg} / \mathrm{d}, P<0.01)$, milk production $(29.6$ vs. $32.7 \mathrm{~kg} / \mathrm{d}, P=0.02)$, and milk lactose yield $(1.58$

\begin{tabular}{|c|c|c|c|c|c|c|c|c|}
\hline \multirow[b]{2}{*}{ Item } & \multicolumn{2}{|c|}{ Jersey } & \multicolumn{2}{|c|}{ Holstein } & \multirow[b]{2}{*}{ SEM } & \multicolumn{3}{|c|}{$P$-value } \\
\hline & Control & $\begin{array}{l}\text { Palmitic } \\
\text { acid }\end{array}$ & Control & $\begin{array}{l}\text { Palmitic } \\
\text { acid }\end{array}$ & & Treatment & Breed & $\begin{array}{c}\text { Treatment } \\
\times \text { breed }\end{array}$ \\
\hline \multicolumn{9}{|l|}{ Intake } \\
\hline $\mathrm{DM}, \mathrm{kg} / \mathrm{d}$ & 22.6 & 22.8 & 25.3 & 24.7 & 0.92 & 0.47 & $<0.01$ & 0.34 \\
\hline DM, $\%$ of $\mathrm{BW}$ & 4.91 & 4.89 & 3.40 & 3.34 & 0.17 & 0.79 & $<0.01$ & 0.89 \\
\hline Rumination time, $\min / \mathrm{d}$ & 448 & 451 & 459 & 453 & 6.67 & 0.58 & 0.50 & 0.88 \\
\hline Milking frequency, no./d & 2.51 & 2.54 & 2.47 & 2.49 & 0.10 & 0.92 & 0.88 & 0.94 \\
\hline \multicolumn{9}{|l|}{ Milk yield, kg/d } \\
\hline Milk & 29.4 & 29.7 & 32.5 & 32.9 & 1.95 & 0.68 & 0.02 & 0.91 \\
\hline $\mathrm{ECM}^{1}$ & 34.0 & 35.8 & 34.2 & 35.6 & 1.82 & 0.10 & 0.99 & 0.77 \\
\hline $3.5 \% \mathrm{FCM}^{2}$ & 33.8 & 35.7 & 34.1 & 35.5 & 1.86 & 0.09 & 0.97 & 0.79 \\
\hline \multicolumn{9}{|l|}{ Milk composition } \\
\hline Fat, $\%$ & 4.67 & 5.10 & 3.81 & 3.97 & 0.18 & 0.01 & $<0.01$ & 0.26 \\
\hline Fat, kg/d & 1.30 & 1.42 & 1.22 & 1.29 & 0.06 & 0.03 & 0.08 & 0.60 \\
\hline Protein, \% & 3.73 & 3.92 & 3.26 & 3.30 & 0.11 & 0.03 & $<0.01$ & 0.20 \\
\hline Protein, $\mathrm{kg} / \mathrm{d}$ & 1.05 & 1.10 & 1.06 & 1.08 & 0.49 & 0.23 & 0.85 & 0.65 \\
\hline Lactose, $\%$ & 4.83 & 4.84 & 4.83 & 4.81 & 0.02 & 0.78 & 0.63 & 0.73 \\
\hline Lactose, $\mathrm{kg} / \mathrm{d}$ & 1.42 & 1.43 & 1.57 & 1.59 & 0.10 & 0.74 & 0.04 & 0.94 \\
\hline BW change, $\mathrm{kg} / \mathrm{d}$ & 0.17 & 0.12 & 0.37 & 0.39 & 0.10 & 0.91 & 0.03 & 0.71 \\
\hline BCS & 3.17 & 3.16 & 3.17 & 3.22 & 0.06 & 0.76 & 0.59 & 0.51 \\
\hline
\end{tabular}

Table 2. Production responses of mid-lactation Jersey and Holstein cows supplemented with or without a palmitic acid-enriched supplement

${ }^{1} \mathrm{ECM}=(0.327 \times \mathrm{kg}$ of milk $)+(12.95 \times \mathrm{kg}$ of milk fat $)+(7.20 \times \mathrm{kg}$ of milk protein $)$.

${ }^{2} 3.5 \% \mathrm{FCM}=(0.4324 \times \mathrm{kg}$ of milk $)+(16.216 \times \mathrm{kg}$ of milk fat $)$. 
vs. $1.42 \mathrm{~kg} / \mathrm{d}, P=0.04$; Table 2). Jersey cows had a greater DMI as a percent of BW $(4.90 \%$ vs. $3.37 \%, P$ $<0.01)$, milk fat content $(4.90 \%$ vs. $3.89 \%, P<0.01)$, and milk protein content $(3.83 \%$ vs. $3.28 \%, P<0.01)$, and tended to have greater milk fat yield (1.36 vs. 1.26 $\mathrm{kg} / \mathrm{d}, P=0.08)$ compared with Holstein cows. Holstein cows gained $0.385 \mathrm{~kg} / \mathrm{d}$ during the experiment, and Jersey cows gained $0.145 \mathrm{~kg} / \mathrm{d}(P=0.03)$. There were no effects of breed on milk protein yield $(P=0.85)$, milk lactose content $(P=0.63), \mathrm{FCM}(P=0.97), \mathrm{ECM}$ $(P=0.99)$, rumination time $(P=0.50)$, or BCS $(P=$ $0.59)$.

\section{Milk Fatty Acids}

There was no treatment $\times$ breed interaction for any milk fatty acid measured $(P \geq 0.16$; Tables 3 and 4$)$. Compared with control, PA treatment decreased milk concentration of $<16$-carbon fatty acids (23.4 vs. 25.0 $\mathrm{g} / 100 \mathrm{~g}$ of fatty acid; $P=0.03)$ and $>16$-carbon fatty acids (35.9 vs. $37.6 \mathrm{~g} / 100 \mathrm{~g}$ of fatty acid; $P<0.01$ ) but increased the concentration of 16 -carbon fatty acids $(39.8$ vs. $36.1 \mathrm{~g} / 100 \mathrm{~g}$ of fatty acid, $P<0.01)$. The PA treatment increased the concentration of C16:0 $(P<$ $0.01)$ but decreased C12:0 $(P<0.01), \mathrm{C} 14: 0(P<0.01)$, and cis-9 $\mathrm{C} 16: 1(P=0.03)$ and tended to decrease $c i s-9$ C18:1:C18:0 ratio $(P=0.07)$. On a yield basis, PA treatment increased 16 -carbon milk fatty acids (502 vs. $422 \mathrm{~g} / \mathrm{d}, P=0.01)$ with no differences observed for the yields of $<16$-carbon fatty acids $(P=0.95)$ and $>16$-carbon fatty acids $(P=0.42)$. The PA treatment increased the yield of C8:0 $(P=0.01), \mathrm{C} 10: 0(P=$ 0.02), C16:0 $(P<0.01), \mathrm{C} 18: 0(P<0.01)$, and cis-9 C18:1 $(P<0.01)$, decreased the yield of $\mathrm{C} 12: 0(P=$ $0.01)$ and $\mathrm{C} 14: 0(P<0.01)$, and tended to decrease the yield of cis-9 C18:1:C18:0 ratio $(P=0.07)$ compared with control.

Compared with Holsteins, Jerseys had greater concentration of $<16$-carbon fatty acids (26.7 vs. 21.7 $\mathrm{g} / 100 \mathrm{~g}$ of fatty acids, $P<0.01)$ and 16 -carbon fatty acids (38.2 vs. $37.7 \mathrm{~g} / 100 \mathrm{~g}$ of fatty acids, $P=0.01$ ) but a decreased concentration of $>16$-carbon fatty acids (39.3 vs. $34.2 \mathrm{~g} / 100 \mathrm{~g}$ of fatty acids, $P<0.01)$. Jersey cows had a greater concentration of C4:0 $(P<0.01)$, C6:0 $(P<0.01)$, C8:0 $(P<0.01)$, C10:0 $(P<0.01)$, $\mathrm{C} 12: 0(P<0.01)$, and $\mathrm{C} 16: 0(P<0.01)$, and tended

Table 3. Milk fatty acid profile of mid-lactation Jersey and Holstein cows supplemented with or without a palmitic acid-enriched supplement

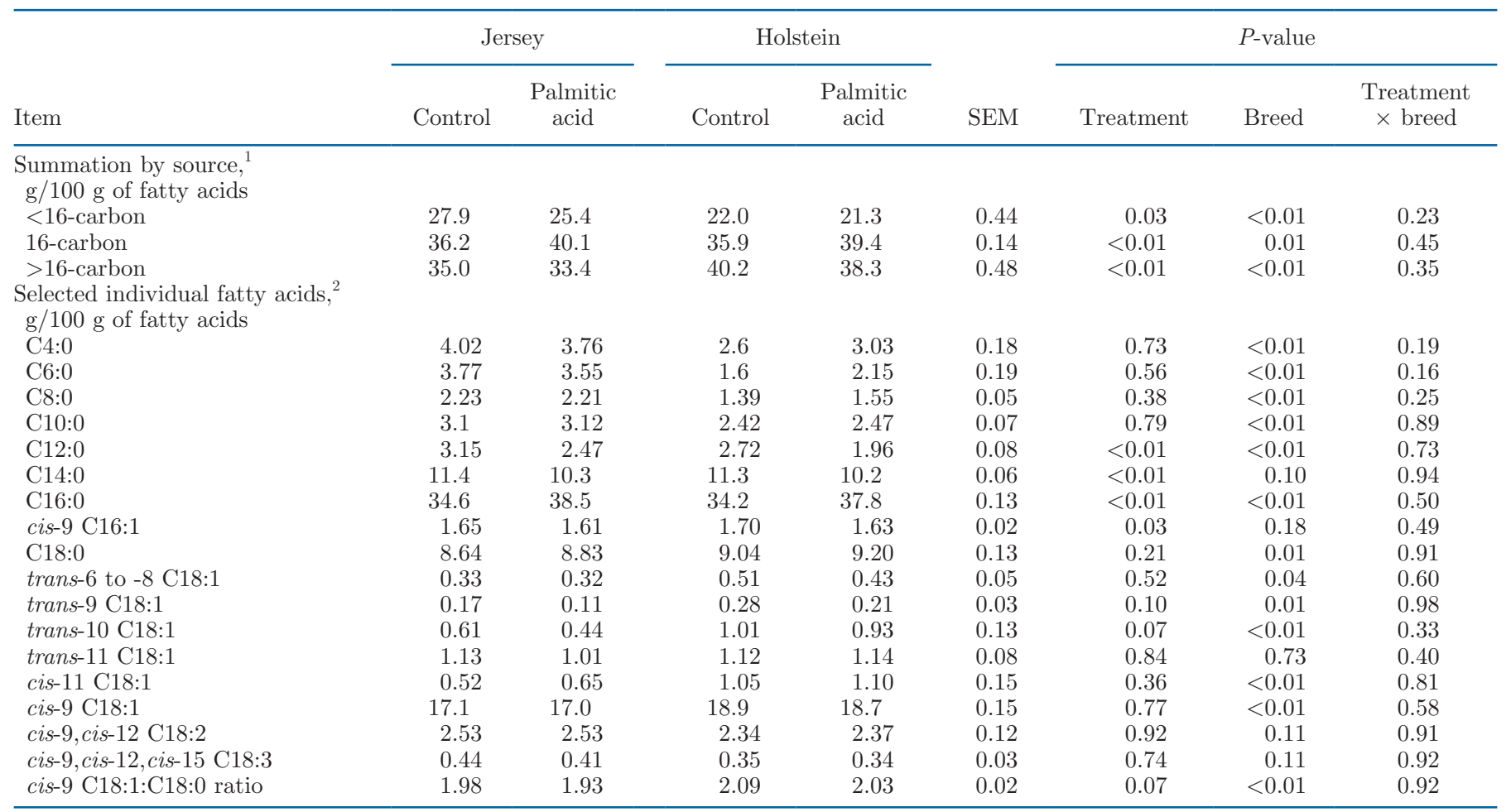

${ }^{1}$ De novo fatty acids originate from mammary de novo synthesis ( $<16$ carbons), preformed fatty acids originate from extraction from plasma ( $>16$ carbons), and 16-carbon fatty acids originate from both sources (C16:0 plus cis-9 C16:1).

${ }^{2} \mathrm{~A}$ total of approximately 70 individual fatty acids were quantified; only select fatty acids are reported in the table. 
Table 4. Milk fatty acid yield of mid-lactation Jersey and Holstein cows supplemented with or without a palmitic acid-enriched supplement

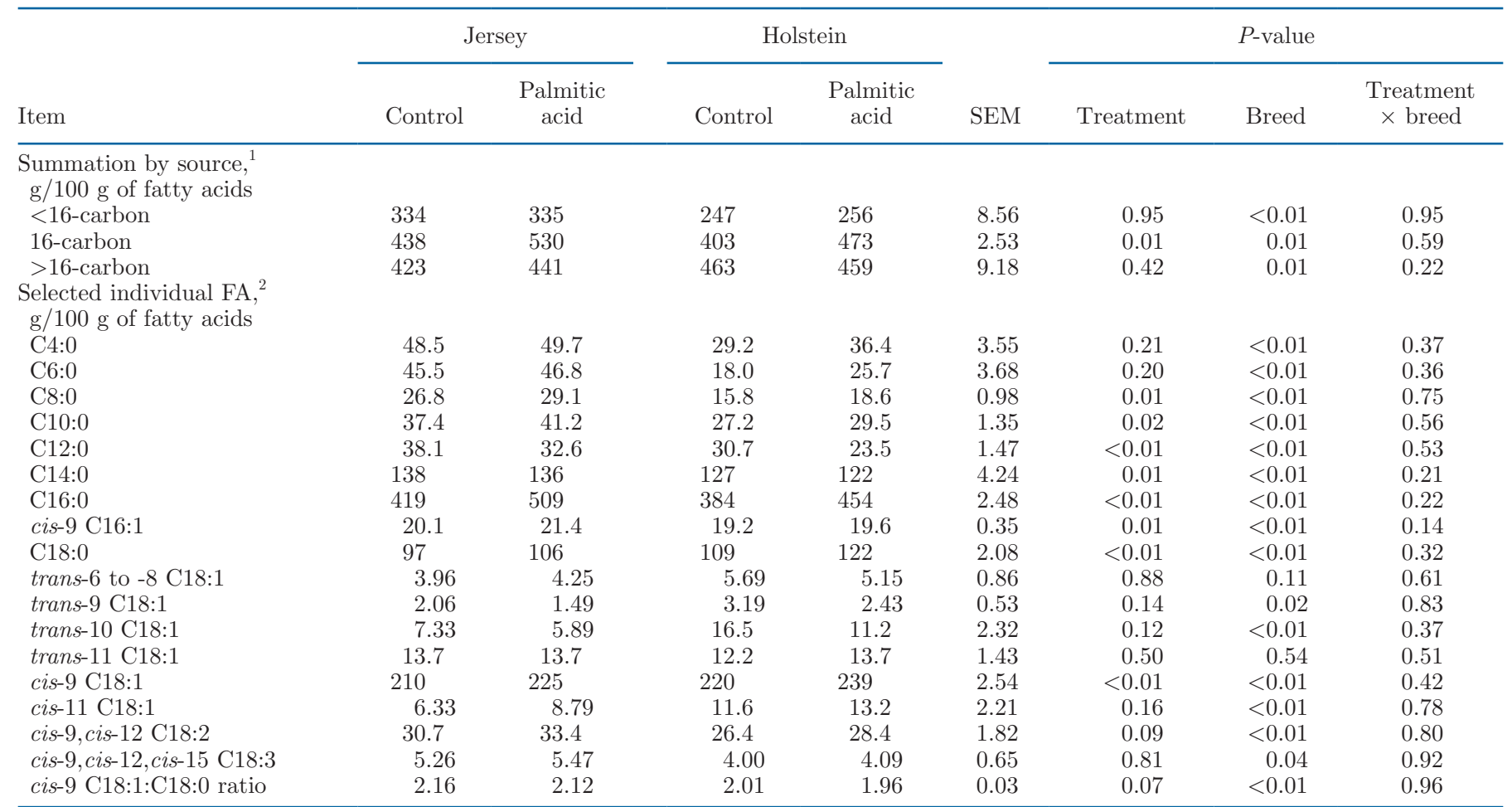

${ }^{1}$ De novo fatty acids originate from mammary de novo synthesis ( $<16$ carbons), preformed fatty acids originate from extraction from plasma (>16 carbons), and 16-carbon fatty acids originate from both sources (C16:0 plus cis-9 C16:1).

${ }^{2} \mathrm{~A}$ total of approximately 70 individual fatty acids were quantified; only select fatty acids are reported in the table.

to have a greater concentration of $\mathrm{C} 14: 0(P=0.10)$. Holsteins had greater concentrations of $\mathrm{C} 18: 0(P<$ $0.01)$, trans-6-8 C18:1 $(P=0.04)$, trans $-9 \mathrm{C} 18: 1(P=$ 0.01), cis-9 C18:1 $(P<0.01)$, cis-11 C18:1 $(P<0.01)$, and cis-9 C18:1:C18:0 ratio $(P<0.01)$. On a yield basis, Jerseys had greater yields of $<16$-carbon fatty acids (335 vs. $251 \mathrm{~g} / \mathrm{d}, P<0.01)$ and 16 -carbon fatty acids ( 484 vs. $438 \mathrm{~g} / \mathrm{d}, P=0.01$ ) but lower $>16$-carbon fatty acids yields $(P=0.01)$ compared with Holsteins. Compared with Holstein cows, Jersey cows had greater yields of $\mathrm{C} 4: 0(P<0.01), \mathrm{C} 6: 0(P<0.01), \mathrm{C} 8: 0(P$ $<0.01)$, C10:0 $(P<0.01)$, C12:0 $(P<0.01)$, C14:0 $(P<0.01)$, C16:0 $(P<0.01)$, cis-9 C16:1 $(P<0.01)$, cis-9,cis-12 C18:2 $(P<0.01)$, cis-9,cis-12,cis-15 C18:3
$(P=0.04)$, and cis-9 C18:1:C18:0 ratio $(P<0.01)$. In contrast, Holstein cows had greater yields of C18:0 ( $P$ $<0.01)$, trans-9 C18:1 $(P=0.02)$, trans-10 C18:1 $(P$ $<0.01)$, cis-9 C18:1 $(P<0.01)$, and cis-11 C18:1 $(P$ $<0.01)$.

\section{Nutrient Digestibility}

There was no treatment $x$ breed interaction for totaltract digestibility of any feed fraction measured $(P \geq$ 0.17 ; Table 5). Compared with control, PA treatment increased DM digestibility (68\% vs. $66 \%, P<0.01$ ) and NDF digestibility ( $46 \%$ vs. $42 \%, P<0.01$ ), but no difference was observed for total fatty acid digestibility

Table 5. Nutrient total-tract digestibility of mid-lactation Jersey and Holstein cows supplemented with or without a palmitic acid-enriched supplement

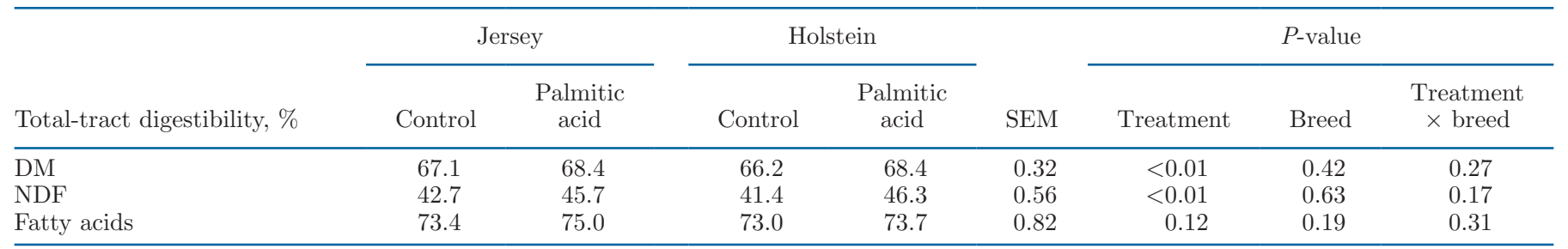


Table 6. Nitrogen metabolism of mid-lactation Jersey and Holstein cows supplemented with or without a palmitic acid-enriched supplement

\begin{tabular}{|c|c|c|c|c|c|c|c|c|}
\hline Item & \multicolumn{2}{|c|}{ Jersey } & \multicolumn{2}{|c|}{ Holstein } & SEM & \multicolumn{3}{|c|}{$P$-value } \\
\hline Nitrogen intake, $\%$ of BW & 0.13 & 0.14 & 0.09 & 0.09 & 0.01 & 0.45 & $<0.01$ & 0.21 \\
\hline BUN, mg/dL & 12.6 & 12.6 & 13.8 & 13.8 & 0.57 & 0.45 & 0.02 & 0.28 \\
\hline MUN, mg/dL & 15.1 & 14.5 & 14.5 & 14.1 & 0.44 & 0.20 & 0.13 & 0.73 \\
\hline Urine total nitrogen, $\mathrm{g} / \mathrm{d}$ & 134 & 115 & 144 & 146 & 6.11 & 0.20 & $<0.01$ & 0.12 \\
\hline Urine total nitrogen, $\%$ of nitrogen intake & 21.0 & 17.9 & 20.5 & 21.7 & 1.15 & 0.18 & 0.04 & 0.55 \\
\hline Urine total nitrogen, $\%$ of $\mathrm{BW}$ & 0.029 & 0.025 & 0.019 & 0.020 & 0.003 & 0.97 & 0.03 & 0.13 \\
\hline
\end{tabular}

$(P=0.12)$. There were no breed differences for digestibility of $\mathrm{DM}(P=0.42), \operatorname{NDF}(P=0.63)$, or total fatty acids $(P=0.19)$.

\section{Nitrogen Metabolism}

There was no treatment $\times$ breed interaction for any nitrogen metabolism variables measured $(P \geq 0.17$; Table 6). Compared with control, PA treatment had no effect on nitrogen intake $(P=0.48)$, nitrogen intake as a percent of BW $(P=0.45)$, BUN $(P=0.45)$, MUN $(P=0.20)$, milk protein nitrogen $(P=0.24)$, milk nitrogen efficiency $(P=0.16)$, urine total nitrogen $(P$ $=0.20)$, urine total nitrogen as a percent of nitrogen intake $(P=0.18)$, or urine total nitrogen as a percent of $\mathrm{BW}(P=0.97)$.

Compared with Holstein cows, Jersey cows had lower nitrogen intake (636 vs. $694 \mathrm{~g} / \mathrm{d}, P<0.01)$, BUN $(12.6$ vs. $13.8 \mathrm{mg} / \mathrm{dL}, P=0.02)$, urine total nitrogen $(124.5$ vs. $145.0 \mathrm{~g} / \mathrm{d}, P<0.01)$, and urine total nitrogen as a percent of nitrogen intake (19.5\% vs $21.1 \%, P=0.04)$. Jersey cows had greater nitrogen intake as a percent of BW (0.15 vs. $0.09 \%$ of BW, $P<0.01)$ and urine total nitrogen as a percent of BW (0.027 vs. $0.019 \%$ of BW, $P=0.03)$ compared with Holstein cows. No breed effect was observed for MUN $(P=0.13)$, milk protein nitrogen $(P=0.69)$, or milk nitrogen efficiency $(P=$ $0.23)$.

\section{DISCUSSION}

Recently, the effects of feeding individual fatty acids on nutrient digestibility, metabolism, and production responses of dairy cows have received attention. The effects of palmitic acid supplements on dairy cow performance and metabolism in postpeak (Piantoni et al., 2013; Mathews et al., 2016) and early-lactation cows (de Souza and Lock, 2019a) has been studied; however, all of these studies were conducted using Holsteins cows. Breed is an important factor that affects production and milk composition of dairy cows. Jersey cows usually have a greater concentration of milk fat compared with Holstein cows, and investigating Jersey cow responses to palmitic acid would be beneficial to help further the understanding of how it can affect production responses in different breeds. Furthermore, previous studies reported an increase in DM and fiber digestibility (Piantoni et al., 2013; de Souza and Lock, 2018). Improvements in ruminal nutrient digestibility may increase the nitrogen incorporation into microbial cells and, consequently, enhance nitrogen utilization. Therefore, the present experiment was designed to investigate the effects of a palmitic acid-enriched supplement on production responses and nitrogen metabolism of mid-lactation Jersey and Holstein cows.

In our study, adding the palmitic acid supplement increased total fatty acid content and the predicted dietary $\mathrm{NE}_{\mathrm{L}}$; therefore, part of the effect on production responses that related to the PA treatment may be associated with greater fatty acid and energy intake. Additionally, considering the high variability in nutrient digestibility among cows and the potential effect that individual fatty acids may have on the digestibility of other fractions, using energy concentrations predicted from the dietary composition is likely inadequate for calculating energy intake and energy balance (Piantoni et al., 2013). In a recent study that fed palmitic acid in place of soyhulls, de Souza et al. (2019c) reported that the NRC (2001) model estimated an increase in $\mathrm{NE}_{\mathrm{L}}$ intake by $1 \mathrm{Mcal} / \mathrm{d}$, whereas the actual measured increase in $\mathrm{NE}_{\mathrm{L}}$ intake was $2.5 \mathrm{Mcal} / \mathrm{d}$. This difference was at least in part associated with the observed increase in NDF digestibility with palmitic acid that the NRC (2001) model is not able to account for in its estimation. Therefore, it is important to consider not only the direct caloric effect of individual fatty acids but also the potential effect on the digestion of other dietary fractions. 
Milk yield response to palmitic acid supplementation has been inconsistent, with some studies reporting an increase in milk yield (Mosley et al., 2007; de Souza and Lock, 2018), and others reporting no effect on milk yield (Lock et al., 2013; Rico et al., 2014a). In our study, we did not observe differences in milk yield due to palmitic acid supplementation in either Holstein or Jersey cows. As reported by Lock et al. (2013), a lack of effect on milk yield may indicate that different partitioning of energy from the supplemental fat occurred, favoring milk fat synthesis. In the present study, we calculated total DMI using internal and external markers to estimate PMR intake. Although external markers are extensively used in research with grazing cows, their use to estimate intake can generate some error due to methodological and analytical errors, time for marker adaptation, and marker recovery. We used $\mathrm{TiO}_{2}$ as a marker because it has been previously validated in sheep (Glindemann et al., 2009), beef cattle (Titgemeyer et al., 2001), and dairy cows (de Souza et al., 2015). In the present study, DMI was not affected by treatment, agreeing with most previous studies feeding palmitic acid supplements to Holstein cows (Piantoni et al., 2013; Rico et al., 2014b; de Souza and Lock, 2019b). The effect of fat supplements on DMI is variable and dependent on the type of fat fed (Rabiee et al., 2012). Feeding saturated fatty acid supplements (up to $3 \%$ of dietary DM) mostly results in no change in DMI (Palmquist and Jenkins, 1980). Dry matter intake as a percent of BW was greater in Jersey cows compared with Holstein cows, and similar results were observed by French (2006).

Milk fat is greatly influenced by chemical characteristics of the feed, which affect nutrient supply to the mammary gland, as well as by other factors including breed, lactation stage, and seasonal variation (Jensen, 2002). Our results indicated that feeding palmitic acid consistently increased milk fat content and yield in both the Holstein and Jersey breeds compared with the control diet. In our study, palmitic acid treatment increased milk fat content $(+0.30$ percentage points) and milk fat yield $(+100 \mathrm{~g} / \mathrm{d})$ compared with control, which is in agreement with several previous studies that fed palmitic acid supplements to Holstein cows (Lock et al., 2013; Piantoni et al., 2013; Mathews et al., 2016). From our results, we estimated that transfer efficiency (additional fat yield/additional supplemental fat) was 36 and $21 \%$ for Jersey and Holstein cows, respectively. For mid-lactation Holstein cows, the transfer efficiency from diet to milk fat ranged from 16 to $24 \%$ in studies feeding palmitic acid supplements (Lock et al., 2013; Piantoni et al., 2013). Enjalbert et al. (2000) reported an apparent transfer efficiency of $46.7 \%$ using duodenal infusions of palmitic acid. de Souza and Lock (2019b) pointed out that differences in fatty acid digestibility may influence the interpretation of the transfer efficiency when supplemental fat is fed. However, we did not observe treatment or breed differences for fatty acid digestibility in our study. Therefore, differences in the transfer efficiency and milk fat responses between Jersey and Holstein cows are likely explained by differences in mammary gland extraction and incorporation of these fatty acids into milk fat.

Overall, the increase in milk fat associated with the palmitic acid treatment occurred due to an increase in yield of 16-carbon milk fatty acids (derived from both de novo synthesis and extraction from plasma), which agrees with previous studies (Rico et al., 2014a; de Souza and Lock, 2018). Tzompa-Sosa et al. (2014) suggested that an increase in the availability of palmitic acid for lipid synthesis in mammary cells may increase the activity of glycerol-3-phosphate acyltransferase in the mammary gland, therefore increasing the proportion of this fatty acid acylated at sn- 1 at the expense of sn-2, and other fatty acids would counter-balance the decrease in the amount of palmitic acid at sn- 2 . Additionally, in our study, milk $<16$-carbon fatty acid concentration, but not yield, was reducedwhen palmitic acid was fed. Feeding palmitic acid only reduced the yield of the medium-chain fatty acids C12:0 and C14:0. Hansen and Knudsen (1987) proposed that the inhibitory effect of certain fatty acids on the de novo synthesis was from competition with newly synthesized medium-chain acyl-CoA for the triglyceride backbone during the esterification steps of mammary lipid synthesis. We also observed that cis-9 C18:1:C18:0 ratio was greater when expressed as concentration and lower when reported on a yield basis for Holstein compared with Jersey cows. This ratio has been proposed as a proxy for the activity of stearoyl-Coa desaturase that plays a pivotal role in regulating the desaturation of saturated to monounsaturated fatty acids (Palmquist, 2006). Similar to our results, a greater cis-9 C18:1: C18:0 ratio (when expressed on a concentration basis) was reported for Holstein compared with Jersey cows (Beaulieu and Palmquist, 1995), which could indicate a different mechanism used by Holstein and Jersey cows to maintain milk fluidity. Altogether, our results with both Jersey and Holstein cows are consistent with previous studies regarding the changes in milk fatty acids when palmitic acid is fed.

Neutral detergent fiber digestibility increased with palmitic acid supplementation in comparison with the control diet in both Holstein and Jersey cows. These results agree with previous studies feeding highly enriched palmitic acid supplements (Warntjes et al., 2008; Rico et al., 2017; de Souza and Lock, 2018). The positive effect on NDF digestibility with palmitic 
acid supplements may be associated with an increase in retention time driven by a rise in cholecystokinin secretion (Piantoni et al., 2013), which was previously reported when saturated fats were fed (Choi et al., 2000). Additionally, rumen bacteria population and bacteria growth are major factors that affect fiber digestion in the rumen (Varga and Kolver, 1997). A recent study (Vargas-Bello-Pérez et al., 2016) reported that a diet supplemented with hydrogenated palm oil (47\% C16:0 and 43\% C18:0) increased ruminal total bacteria measured as copies of $16 \mathrm{~S}$ ribosomal DNA and the prevalence of some fibrolytic bacteria (e.g., Prevotella spp.) compared with a nonfat control diet and soybean oil, indicating a potential role of the fatty acid profile of supplemental fat on rumen microbes. Alternatively, bacteria typically synthesize palmitic acid to produce phosphatidic acid, the precursor for fatty acid components in membranes of Butyrivibrio bacteria (Hackmann and Firkins, 2015). However, if dietary palmitic acid could be incorporated into rumen bacterial membranes, considerable carbon and energy precursors would be spared, which may favor bacterial growth (Vlaeminck et al., 2006), potentially increasing NDF digestibility. Although the mechanisms by which palmitic acid increases NDF digestibility are not completely understood, the topic deserves further research.

Our nitrogen metabolism data suggest that palmitic acid, despite its ability to increase NDF digestibility and potentially provide more energy to the ruminal microbes, does not enhance nitrogen utilization in the rumen. Higher fermentable carbohydrate loads have shown to increase nitrogen utilization and incorporation (Cameron et al., 1991). Similar to our results, a recent study (Wenner and St-Pierre, 2019) feeding increasing level of palmitic acid $(0,1,2$, and $3 \%$ of diet $\mathrm{DM})$ in continuous culture fermenters indicated that palmitic acid increased NDF and ADF digestibility but did not affect bacterial nitrogen flow and ammonia levels. Additionally, bacterial nitrogen yield per NDF or $\mathrm{ADF}$ digested $(\mathrm{g} / \mathrm{kg})$ tended to increase with palmitic acid supplementation, which suggests an improvement in microbial efficiency but not in microbial yield. Further research is needed to determine the mechanism by which palmitic acid affects fiber digestion. Although a limited number of studies compared nutrient excretion between Jersey and Holstein cows, previous studies suggest that Jersey cows excrete $\sim 30 \%$ less fecal and urinary nitrogen than Holstein cows (Kauffman and St-Pierre, 2001; Knowlton et al., 2010). Although we observed the same trend of response with lower urinary nitrogen excretion as the above-mentioned studies, the magnitude of response was smaller in our study, which was likely associated with differences in the basal diet and levels of fermentable carbohydrates across different studies. Our results indicated that Jersey cows more efficiently utilized nitrogen, with greater nitrogen intake as a percent of BW and lower BUN and urine total nitrogen. This may deserve future investigation, as the need for reduced environmental impact continues to affect dairy production.

\section{CONCLUSIONS}

This study shows that a palmitic acid-enriched supplement consistently improved milk fat yield and content and protein content in both Jersey and Holstein cows compared with soyhulls. Although palmitic acid increased fiber digestibility, nitrogen metabolism was not affected by fatty acid supplementation. Our results suggest that Jersey cows had lower urinary nitrogen excretion than Holstein cows, but production responses to a palmitic acid-enriched supplement were similar across breeds. This experiment extends our understanding that dietary supplementation of palmitic acid can improve milk fat yield of the 2 most common breeds within the US dairy industry.

\section{ACKNOWLEDGMENTS}

We thank Perdue AgriBusiness (Salisbury, MD) for the partial support of this experiment. This research was supported by the Utah Agricultural Experiment Station at Utah State University (Logan, UT), and approved as journal paper \#9265. The authors have not stated any conflicts of interest.

\section{REFERENCES}

AOAC. 1990. Official Methods of Analysis Vol. I. 15th ed. AOAC, Arlington, VA.

AOAC International. 2000. Official Methods of Analysis. 17th ed. AOAC International, Arlington, VA.

Batistel, F., J. de Souza, and F. A. P. Santos. 2017. Corn grain-processing method interacts with calcium salts of palm fatty acids supplementation on milk production and energy balance of earlylactation cows grazing tropical pasture. J. Dairy Sci. 100:53435357. https://doi.org/10.3168/jds.2016-12503.

Beaulieu, A. D., and D. L. Palmquist. 1995. Differential effects of high fat diets on fatty acid composition in milk of Jersey and Holstein cows. J. Dairy Sci. 78:1336-1344. https://doi.org/10.3168/ jds.S0022-0302(95)76755-8.

Bender, R. W., D. E. Cook, and D. K. Combs. 2016. Comparison of in situ versus in vitro methods of fiber digestion at 120 and 288 hours to quantify the indigestible neutral detergent fiber fraction of corn silage samples. J. Dairy Sci. 99:5394-5400. https://doi.org/ 10.3168/jds.2015-10258.

Cameron, M. R., T. H. Klusmeyer, G. L. Lynch, J. H. Clark, and D. R. Nelson. 1991. Effects of urea and starch on rumen fermentation, nutrient passage to the duodenum, and performance of cows. J. Dairy Sci. 74:1321-1336. https://doi.org/10.3168/jds.S0022 -0302(91)78288-X.

Chizzotti, M. L., S. C. Valadares Filho, R. F. D. Valadares, F. H. M. Chizzotti, and L. O. Tedeschi. 2008. Determination of creatinine excretion and evaluation of spot urine sampling in Holstein cattle. 
Livest. Sci. 113:218-225. https://doi.org/10.1016/j.livsci.2007.03 .013 .

Choi, B. R., D. L. Palmquist, and M. S. Allen. 2000. Cholecystokinin mediates depression of feed intake in dairy cattle fed high fat diets. Domest. Anim. Endocrinol. 19:159-175. https://doi.org/10.1016/ S0739-7240(00)00075-8.

Cochran, R. C., D. C. Adams, J. D. Wallace, and M. L. Galyean. 1986. Predicting digestibility of different diets with internal markers: Evaluation of four potential markers. J. Anim. Sci. 63:1476-1483. https://doi.org/10.2527/jas1986.6351476x.

de Souza, J., F. Batistel, K. C. Welter, M. M. Silva, D. F. Costa, and F. A. Portela Santos. 2015. Evaluation of external markers to estimate fecal excretion, intake, and digestibility in dairy cows. Trop. Anim. Health Prod. 47:265-268. https://doi.org/10.1007/ s11250-014-0674-6.

de Souza, J., and A. L. Lock. 2018. Long-term palmitic acid supplementation interacts with parity in lactating dairy cows: Production responses, nutrient digestibility, and energy partitioning. J. Dairy Sci. 101:3044-3056. https://doi.org/10.3168/jds.2017-13946.

de Souza, J., and A. L. Lock. 2019a. Effects of timing of palmitic acid supplementation on production responses of early-lactation dairy cows. J. Dairy Sci. 102:260-273. https://doi.org/10.3168/jds.2018 $-14976$.

de Souza, J., and A. L. Lock. 2019b. Milk production and nutrient digestibility responses to triglyceride or fatty acid supplements enriched in palmitic acid. J. Dairy Sci. 102:4155-4164. https://doi .org/10.3168/jds.2018-15690.

de Souza, J., C. L. Preseault, and A. L. Lock. 2018. Altering the ratio of dietary palmitic, stearic, and oleic acids in diets with or without whole cottonseed affects nutrient digestibility, energy partitioning, and production responses of dairy cows. J. Dairy Sci. 101:172-185. https://doi.org/10.3168/jds.2017-13460.

de Souza, J., C. Strieder-Barboza, G. A. Contreras, and A. L. Lock. 2019c. Effects of timing of palmitic acid supplementation during early lactation on nutrient digestibility, energy balance, and metabolism of dairy cows. J. Dairy Sci. 102:274-287. https://doi.org/ 10.3168/jds.2018-14977.

Enjalbert, F., M. C. Nicot, C. Bayourthe, and R. Moncoulon. 2000. Effects of duodenal infusions of palmitic, stearic, or oleic acids on milk composition and physical properties of butter. J. Dairy Sci. 83:1428-1433. https://doi.org/10.3168/jds.S0022-0302(00)75012 $-0$.

French, P. D. 2006. Dry matter intake and blood parameters of nonlactating Holstein and Jersey cows in late gestation. J. Dairy Sci. 89:1057-1061. https://doi.org/10.3168/jds.S0022-0302(06)72173 $-7$.

Glasser, F., M. Doreau, A. Ferlay, and Y. Chilliard. 2007. Technical note: Estimation of milk fatty acid yield from milk fat data. J. Dairy Sci. 90:2302-2304. https://doi.org/10.3168/jds.2006-870.

Glindemann, T., B. M. Tas, C. Wang, S. Alvers, and A. Susenbeth. 2009. Evaluation of titanium dioxide as an inert marker for estimating faecal excretion in grazing sheep. Anim. Feed Sci. Technol. 152:186-197. https://doi.org/10.1016/j.anifeedsci.2009.04.010.

Hackmann, T. J., and J. L. Firkins. 2015. Electron transport phosphorylation in rumen butyrivibrios: Unprecedented ATP yield for glucose fermentation to butyrate. Front. Microbiol. 6:622. https:// doi.org/10.3389/fmicb.2015.00622.

Hall, M. B. 2009. Determination of starch, including maltooligosaccharides, in animal feeds: Comparison of methods and a method recommended for AOAC collaborative study. J. AOAC Int. 92:42-49. https://doi.org/10.1093/jaoac/92.1.42.

Hansen, H. O., and J. Knudsen. 1987. Effect of exogenous long-chain fatty acids on lipid biosynthesis in dispersed ruminant mammary gland epithelial cells: Esterification of long-chain exogenous fatty acids. J. Dairy Sci. 70:1344-1349. https://doi.org/10.3168/jds .S0022-0302(87)80154-6.

Hara, A., and N. S. Radin. 1978. Lipid extraction of tissues with a low-toxicity solvent. Anal. Biochem. 90:420-426. https://doi.org/ 10.1016/0003-2697(78)90046-5.

Hardie, L. C., L. E. Armentano, R. D. Shaver, M. J. VandeHaar, D. M. Spurlock, C. Yao, S. J. Bertics, F. E. Contreras-Govea, and K. A.
Weigel. 2015. Considerations when combining data from multiple nutrition experiments to estimate genetic parameters for feed efficiency. J. Dairy Sci. 98:2727-2737. https://doi.org/10.3168/jds .2014-8580.

Jenkins, T. C. 2010. Technical note: Common analytical errors yielding inaccurate results during analysis of fatty acids in feed and digesta samples. J. Dairy Sci. 93:1170-1174. https://doi.org/10 $.3168 /$ jds.2009-2509.

Jensen, R. G. 2002. The composition of bovine milk lipids: January 1995 to December 2000. J. Dairy Sci. 85:295-350. https://doi.org/ 10.3168/jds.S0022-0302(02)74079-4.

Kauffman, A. J., and N. R. St-Pierre. 2001. The relationship of milk urea nitrogen to urine nitrogen excretion in Holstein and Jersey cows. J. Dairy Sci. 84:2284-2294. https://doi.org/10.3168/jds .S0022-0302(01)74675-9.

Knowlton, K. F., V. A. Wilkerson, D. P. Casper, and D. R. Mertens. 2010. Manure nutrient excretion by Jersey and Holstein cows. J. Dairy Sci. 93:407-412. https://doi.org/10.3168/jds.2009-2617.

Lock, A. L., C. L. Preseault, J. E. Rico, K. E. DeLand, and M. S. Allen. 2013. Feeding a C16:0-enriched fat supplement increased the yield of milk fat and improved conversion of feed to milk. J. Dairy Sci. 96:6650-6659. https://doi.org/10.3168/jds.2013-6892.

Mathews, A. T., J. E. Rico, N. T. Sprenkle, A. L. Lock, and J. W. McFadden. 2016. Increasing palmitic acid intake enhances milk production and prevents glucose-stimulated fatty acid disappearance without modifying systemic glucose tolerance in mid-lactation dairy cows. J. Dairy Sci. 99:8802-8816. https://doi.org/10 $.3168 /$ jds.2016-11295.

Mosley, S. A., E. E. Mosley, B. Hatch, J. I. Szasz, A. Corato, N. Zacharias, D. Howes, and M. A. McGuire. 2007. Effect of varying levels of fatty acids from palm oil on feed intake and milk production in Holstein cows. J. Dairy Sci. 90:987-993. https://doi.org/10.3168/ jds.S0022-0302(07)71583-7.

Myers, W. D., P. A. Ludden, V. Nayigihugu, and B. W. Hess. 2004. Technical Note: A procedure for the preparation and quantitative analysis of samples for titanium dioxide. J. Anim. Sci. 82:179-183. https://doi.org/10.2527/2004.821179x.

NRC. 2001. Nutrient Requirements of Dairy Cattle, 7th rev. ed. The National Academies Press, Washington, DC.

Palladino, R. A., F. Buckley, R. Prendiville, J. J. Murphy, J. Callan, and D. A. Kenny. 2010. A comparison between Holstein-Friesian and Jersey dairy cows and their F(1) hybrid on milk fatty acid composition under grazing conditions. J. Dairy Sci. 93:2176-2184. https://doi.org/10.3168/jds.2009-2453.

Palmquist, D. L. 2006. Milk fat: Origin of fatty acids and influence of nutritional factors thereon. Pages 43-92 in Advanced Dairy Chemistry. Vol. 2: Lipids. P. F. Fox and P. L. H. McSweeney, ed. Springer US, Boston, MA

Palmquist, D. L., and T. C. Jenkins. 1980. Fat in lactation rations. J. Dairy Sci. 63:1-14. https://doi.org/10.3168/jds.S0022 $-0302(80) 82881-5$.

Piantoni, P., A. L. Lock, and M. S. Allen. 2013. Palmitic acid increased yields of milk and milk fat and nutrient digestibility across production level of lactating cows. J. Dairy Sci. 96:7143-7154. https://doi .org/10.3168/jds.2013-6680.

Powell, J. M., D. B. Jackson-Smith, D. F. McCrory, H. Saam, and M. Mariola. 2006. Validation of feed and manure data collected on Wisconsin dairy farms. J. Dairy Sci. 89:2268-2278. https://doi .org/10.3168/jds.S0022-0302(06)72298-6.

Rabiee, A. R., K. Breinhild, W. Scott, H. M. Golder, E. Block, and I. J. Lean. 2012. Effect of fat additions to diets of dairy cattle on milk production and components: A meta-analysis and metaregression. J. Dairy Sci. 95:3225-3247. https://doi.org/10.3168/ jds.2011-4895.

Rico, D. E., Y. Ying, and K. J. Harvatine. 2014a. Effect of a highpalmitic acid fat supplement on milk production and apparent total-tract digestibility in high- and low-milk yield dairy cows. J. Dairy Sci. 97:3739-3751. https://doi.org/10.3168/jds.2013-7341.

Rico, J. E., M. S. Allen, and A. L. Lock. 2014b. Compared with stearic acid, palmitic acid increased the yield of milk fat and im- 
proved feed efficiency across production level of cows. J. Dairy Sci. 97:1057-1066. https://doi.org/10.3168/jds.2013-7432.

Rico, J. E., J. de Souza, M. S. Allen, and A. L. Lock. 2017. Nutrient digestibility and milk production responses to increasing levels of palmitic acid supplementation vary in cows receiving diets with or without whole cottonseed. J. Anim. Sci. 95:436-446.

Russell, J. B., C. J. Sniffen, and P. J. Van Soest. 1983. Effect of carbohydrate limitation on degradation and utilization of casein by mixed rumen bacteria. J. Dairy Sci. 66:763-775. https://doi.org/ 10.3168/jds.S0022-0302(83)81856-6.

Schauff, D. J., J. P. Elliott, J. H. Clark, and J. K. Drackley. 1992. Effects of feeding lactating dairy cows diets containing whole soybeans and tallow. J. Dairy Sci. 75:1923-1935. https://doi.org/10 .3168/jds.S0022-0302(92)77952-1.

Schirmann, K., M. A. von Keyserlingk, D. M. Weary, D. M. Veira, and W. Heuwieser. 2009. Technical note: Validation of a system for monitoring rumination in dairy cows. J. Dairy Sci. 92:6052-6055. https://doi.org/10.3168/jds.2009-2361.

Sukhija, P. S., and D. L. Palmquist. 1988. Rapid method for determination of total fatty acid content and composition of feedstuffs and feces. J. Agric. Food Chem. 36:1202-1206. https://doi.org/10 $.1021 /$ jf00084a019.

Titgemeyer, E. C., C. K. Armendariz, D. J. Bindel, R. H. Greenwood, and C. A. Loest. 2001. Evaluation of titanium dioxide as a digestibility marker for cattle. J. Anim. Sci. 79:1059-1063. https://doi .org/10.2527/2001.7941059x.

Tzompa-Sosa, D. A., G. A. van Aken, A. C. van Hooijdonk, and H. J. van Valenberg. 2014. Influence of C16:0 and long-chain saturated fatty acids on normal variation of bovine milk fat triacylglycerol structure. J. Dairy Sci. 97:4542-4551. https://doi.org/10.3168/jds .2014-7937.

Van Soest, P. J., J. B. Robertson, and B. A. Lewis. 1991. Methods for dietary fiber, neutral detergent fiber, and nonstarch polysaccharides in relation to animal nutrition. J. Dairy Sci. 74:3583-3597. https://doi.org/10.3168/jds.S0022-0302(91)78551-2.

Varga, G. A., and E. S. Kolver. 1997. Microbial and animal limitations to fiber digestion and utilization. J. Nutr. 127(Suppl 5):819S-823S. https://doi.org/10.1093/jn/127.5.819S.
Vargas-Bello-Pérez, E., N. Cancino-Padilla, J. Romero, and P. C. Garnsworthy. 2016. Quantitative analysis of ruminal bacterial populations involved in lipid metabolism in dairy cows fed different vegetable oils. Animal 10:1821-1828. https://doi.org/10.1017/ S1751731116000756.

Vlaeminck, B., V. Fievez, A. R. J. Cabrita, A. J. M. Fonseca, and R. J. Dewhurst. 2006. Factors affecting odd- and branched-chain fatty acids in milk: A review. Anim. Feed Sci. Technol. 131:389-417. https://doi.org/10.1016/j.anifeedsci.2006.06.017.

Warntjes, J. L., P. H. Robinson, E. Galo, E. J. DePeters, and D. Howes. 2008. Effects of feeding supplemental palmitic acid (C16:0) on performance and milk fatty acid profile of lactating dairy cows under summer heat. Anim. Feed Sci. Technol. 140:241-257. https: //doi.org/10.1016/j.anifeedsci.2007.03.004.

Weiss, W. P., D. E. Shoemaker, L. R. McBeth, and N. R. St-Pierre. 2013. Effects on lactating dairy cows of oscillating dietary concentrations of unsaturated and total long-chain fatty acids. J. Dairy Sci. 96:506-514. https://doi.org/10.3168/jds.2012-5835.

Wenner, B. A., and N. R. St-Pierre. 2019. Palmitic fatty acid dosed in continuous culture fermeters increases fiber digestibility estimates. J. Dairy Sci. 102(Suppl. 1):316. (Abstr.)

Wildman, E. E., G. M. Jones, P. E. Wagner, R. L. Boman, H. F Troutt Jr., and T. N. Lesch. 1982. A dairy cow body condition scoring system and its relationship to selected production characteristics. J. Dairy Sci. 65:495-501. https://doi.org/10.3168/jds .S0022-0302(82)82223-6

\section{ORCIDS}

Jonas de Souza @i https://orcid.org/0000-0002-7686-7079

Alejandro Relling @ https://orcid.org/0000-0002-1288-3037

Fernanda Batistel ๑ https://orcid.org/0000-0001-7313-7153 